\title{
労働災害における休業見込期間と実休業日数の差異 一労働者死傷病報告と実休業日数との乘離一
}

\author{
加 藤 善 $土^{* 1,2}$ ，太田充 彦*2，八谷寛*2
}

\begin{abstract}
労働基準監督署では, 労働災害の重篤度を休業見込期間により判断し，労働災害防止施策を展開している. しかし，労働災害の休業が当初の休業見込期間を超えて長期に及ぶことがある．的確な労働災害防止施策を展 開するためには，休業期間を早期に正確に把握することが重要となる．そこで某労働基準監督署管内の過去 3 年間に発生した労働災害 1,672 件 (男性 1,204 名，女性 468 名)について，事業場から報告される労働者死傷病 報告と労働者災害補償内容を対比し，休業見込期間と実際の実休業日数の乘離状況を調べ，業種，事業場規模， 性別，年齢，業務経験期間，平均賃金との関連を検討した。

休業見込期間を超えて実際に休業した者の割合は男性で $71.2 \%$ ，女性で $63.9 \%$ あった。休業見込期間（中 央值：男性 30 日，女性 28 日）と実休業日数（中央值：男性 50 日，女性 39日）は男性の方が長かった。休業見 込期間を超えて休業する者の割合は，男性において事業場業種，事業場規模，年齢で有意な差が認められた． また，実休業日数／休業見込期間比の中央值は男性 1.38 , 女性 1.20 と男女間で有意な差があった.

労働災害の重篤度を休業見込期間で判断することは，重篤度を過小評価する可能性が高く，実休業日数が 休業見込期間を超える割合には，男女で差があった。 キーワード: 労働災害, 休業見込, 業種, 年齢, 性別
\end{abstract}

\section{1 はじめに}

平成 29 年の労働災害による死亡者数は前年より 50 名 増加して978名であったが，わが国の労働災害の死亡者 数は, 昭和 36 年の 6,712 人をピークとして長期的には減 少傾向を示している ${ }^{1)}$. 一方で, 労働災害による被災者 数は増加傾向にあり年間 55 万人を超えており，その社 会的・経済的な損失は大きい ${ }^{1)}$. 労働災害により 4 日以 上の休業をした労働者は, 平成29年では全産業で 120,460 人 (死亡 978 人を含む), 死傷者 1 人平均労働損 失日数が 55.0 日となっている ${ }^{2)}$.

休業を伴う労働災害が発生した場合, 労働災害発生事 業場は労働基準監督署に労働者死傷病報告を提出す $る^{3)}$. 労働者死傷病報告により報告された休業見込期間 は, 労働災害の重篤度を判断する重要な指標となってい る ${ }^{4)}$. しかし, 労働者死傷病報告に記載される休業見込 期間に対して実休業日数は概して長く, 休業見込期間か ら労衔災害の重篤度を判断すると的確な再発防止策が困 難となることがある。また生産管理において，休業によ る労働力損失を正確に推定することは切実な問題であ り, 予想を超える長期休業は労働力確保の観点から好ま しくない，さらに被災者自身にとっても，予想を超える 長期休業はキャリアパスの観点からも好ましくない.

平成 30 年に策定された第 13 次労働災害防止計画 ${ }^{4}$ で は,「重篤な災害の防止対策」として，休業6か月以上 の労働災害については，原因究明や防止対策を検討する

原稿受付 2019年 2 月 15 日 (Received date: February 15, 2019)

原稿受理 2019年 7 月 10 日 (Accepted date: July 10, 2019)

J-STAGE Advance published date: August 31, 2019

* 1 元名古屋南労働基準監督署

*2 藤田医科大学医学部公衆衛生学講座

連絡先：干470-1192 愛知県豊明市沓掛町田楽ヶ窪 1-98

藤田医科大学医学部公衆衛生学 加藤善士

E-mail: katouys@fujita-hu.ac.jp

doi: 10.2486/josh.JOSH-2019-0009-CHO
ことが明記されている．労働災害による休業日数を早期 に正確に把握できれば，重篤な災害にかかる調査等が迅 速に行われ，労働災害防止に資すると考える，従来から 労働災害発生は安全管理体制等が脆弱な中小規模事業場 に多いとされている1 . しかし，労働災害による休業見 込期間と実休業日数の乘離が事業場属性（業種，事業場 規模等）や被災労働者属性（年齢，性別，経験期間，平 均賃金等）によって異なるかを検討した報告は少ない.

本研究の目的は, 中部地方の某労働基準監督署管内に おいて平成 26 年から 28 年の 3 年間に発生した労働災害 についての業務統計データを用いて休業見込期間と実休 業日数の差異を記述することと，その差異に業種，事業 場規模，被災者性別，年齢，経験期間，平均賃金額が関 連するかを明らかにすることである。これにより，どの ような事業場・被災労働者属性があれば休業日数が休業 見込期間よりも長くなる（あるいは短くなる）可能性が あるかを予測すること，および，休業日数が休業見込期 間よりも長くなる（あるいは短くなる）被災労働者に対 して労衝安全衛生上の対策を具体的に講じることが可能 になると考える。

\section{2 研究方法}

\section{1) 対象者}

中部地方 $\mathrm{A}$ 労働基準監督署（管内に約 22,000 事業場, 労衝者数約 24 万人) に, 労働安全衛生法 (以下「労安法」) に基づく労働者死傷病報告が提出された労働災害を対象 とした ${ }^{3)}$.

平成 30 年 1 月末時点で，平成 26 年 1 月 1 日から平成 28 年 12 月 31 日の 3 年間に発生した休業 4 日以上の労働 災害 ( 1,893 件) のうち, 労働者災害補償保険法 (以下「労 災法」という）による休業補償給付請求（平成26年〜 29 年の 4 年間) が比較できる労働災害（1,672 件）を分 
析対象とした。

本研究は労働基準監督署における業務統計を個人名・ 事業場名等が特定できないように用いた検討であり，人 を対象とする医学系研究に関する倫理指針の対象となら ない。

\section{2) 調査内容}

労働者死傷病報告から休業見込期間, 事業場（労働者 数) 規模, 経験期間, 年齢, 性別等を, 休業補償給付請 求内容から実休業日数, 平均賃金を把握した。

- 労働者死傷病報告 ${ }^{5)}$

事業場内で休業 4 日以上の労働災害が発生した場合, 労働者死傷病報告が所轄労働基準監督署に提出される. 提出義務は, 労安法により事業主に課されている. 事業 主は, 事業場において発生した労働災害について, 被災 者属性 (年齢, 性別等), 災害発生状況, 傷病名, 休業 見込期間, 派遣元先等を記載した労働者死傷病報告を遅 帯なく,所轄労働基準監督署に提出しなければならない.

- 休業見込期間

労働者死傷病報告に記載されている休業見込期間とし た. 月単位で記載されている場合は 1 月を 30 日で換算 した. 休業見込期間は一般に医師の診断書記載内容に基 づいて記載される.

・ 経験期間

労働者死傷病報告に記載されている被災時の業務経験 期間とした。

\section{- 休業補償給付請求 ${ }^{6)}$}

労災法による休業補償給付請求は, 原則, 被災者本人 が請求書に主治医と事業主の証明を得た上, 所轄労働基 準監督署に提出して請求する.

- 実休業日数

休業補償給付は, 療養のために労働できなかった期間 で，かつ事業主から賃金を受けていない期間について請 求されるため, 請求書上の休業開始日と休業終了日の差 を実休業日数とした. 災害発生日から最長 4 年間（最短 1 年間) の休業期間を把握しているため, 実休業日数が 365日を超える場合は, 365日とした。休業終了日は労 災法上の休業補償給付請求の最終日であり, 療養が完了 した日（治ゆ・症状固定日）ではない．

- 平均賃金額 $(\text { 日額 })^{8)}$

平均傊金額は, 被災者の被災直前3ヶ月間の賃金合計
表 1 被災者の休業見込期間 - 実休業日数 - 所属事業場業種 · 労働者数・年齢・経験期間 $\cdot$ 平均賃金

\begin{tabular}{|c|c|c|c|c|}
\hline & & 男 ( $n=1 ， 204)$ & 女 $(n=468)$ & $p$ \\
\hline \multirow{3}{*}{$\begin{array}{ll}\text { 休 } & \text { 込 } \\
\text { 業 } & \text { 期 } \\
\text { 見 } & \text { 間 }\end{array}$} & 中央値（日） & 30 & 28 & $<0.001$ \\
\hline & 最小值（日） & 4 & 4 & \\
\hline & 最大値（日） & 540 & 360 & \\
\hline \multirow{3}{*}{$\begin{array}{ll}\text { 実 } & \\
\text { 休 } & \\
\text { 業 } & \text { 日 } \\
& \text { 数 }\end{array}$} & 中央值（日） & 50 & 39 & $<0.001$ \\
\hline & 最小値（日） & 4 & 4 & \\
\hline & 最大值（日） & 365 & 365 & \\
\hline \multirow[b]{2}{*}{ 業 } & 製造業 & $363 \quad(30.1 \%)$ & $123 \quad(26.3 \%)$ & \\
\hline & 建設業 & $144(12.0 \%)$ & $4 \quad(0.9 \%)$ & $<0.001$ \\
\hline \multirow[t]{2}{*}{ 種 } & 運送 - 港湾業 & $429 \quad(35.6 \%)$ & $33 \quad(7.1 \%)$ & \\
\hline & 商業 · その他 & $268 \quad(22.3 \%)$ & $308 \quad(65.8 \%)$ & \\
\hline \multirow{3}{*}{$\begin{array}{l}\text { 労 } \\
\text { 働 } \\
\text { 者 } \\
\text { 数 }\end{array}$} & 中央値 (人) & 26 & 51 & $<0.001$ \\
\hline & 最小値 (人) & 1 & 1 & \\
\hline & 最大値 (人) & 8,538 & 6,430 & \\
\hline \multirow{3}{*}{$\begin{array}{l}\text { 年 } \\
\text { 齢 }\end{array}$} & 中央値 (歳) & 46 & 53 & $<0.001$ \\
\hline & 最小値 (歳) & 17 & 16 & \\
\hline & 最大値 (歳) & 82 & 82 & \\
\hline \multirow{3}{*}{$\begin{array}{l}\text { 経 } \\
\text { 験 } \\
\text { 期 } \\
\text { 間 }\end{array}$} & 中央値 (月) & 48 & 36 & $<0.001$ \\
\hline & 最小値 (月) & 0 & 0 & \\
\hline & 最大値 (月) & 720 & 576 & \\
\hline \multirow{3}{*}{$\begin{array}{l}\text { 平 } \\
\text { 均 } \\
\text { 貸 } \\
\text { 金 }\end{array}$} & 中央值 (円) & $9,442.83$ & $4,632.93$ & $<0.001$ \\
\hline & 最小値 (円) & $1,708.80$ & 652.17 & \\
\hline & 最大値 (円) & $28,588.30$ & $19,336.82$ & \\
\hline
\end{tabular}

p 値はMann-WhitneyのU検定（業種はカイ2乗検定）による

を暦日数で除した額である．短時間労働者等で平均賃金 額が低額な場合には，別途定められた休業補償給付の最 低額（平成 29 年 8 月時点では 3,920円）が適用される.

\section{3）分析方法}

対象者の休業見込期間，実休業日数，所属事業場属性 (業種・規模)，年齢，経験期間，平均賃金および休業見 込期間と実休業日数の分布を示した後, 実休業日数が休 業見込期間を超えたことが所属事業場属性(業種・規模), 年齢, 経験期間, 平均賃金と関連したかを解析した. 次 いで実休業日数／休業見込期間比を算出し,これが所属 事業場労働者数, 年齢, 経験期間, 平均賃金と相関する かを調べた。これらの分析は男女別に行った。検定には $\chi 2$ 乗検定, Mann-WhitneyのU検定, Spearman相関係 数を利用した. 解析には, IBM SPSS Statistics 25 を使用 した.

表2 休業見込期間と実休業日数の状況

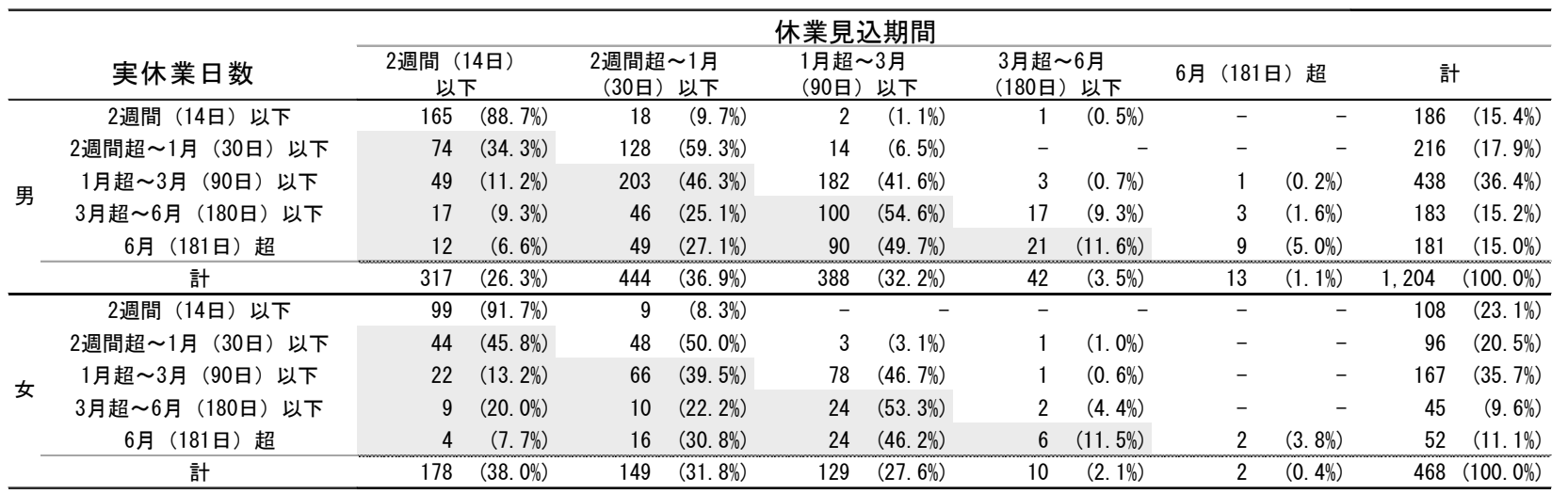


表 3 休業見込期間以内・超えと事業場規模・年齢・経験期間・平均賃金

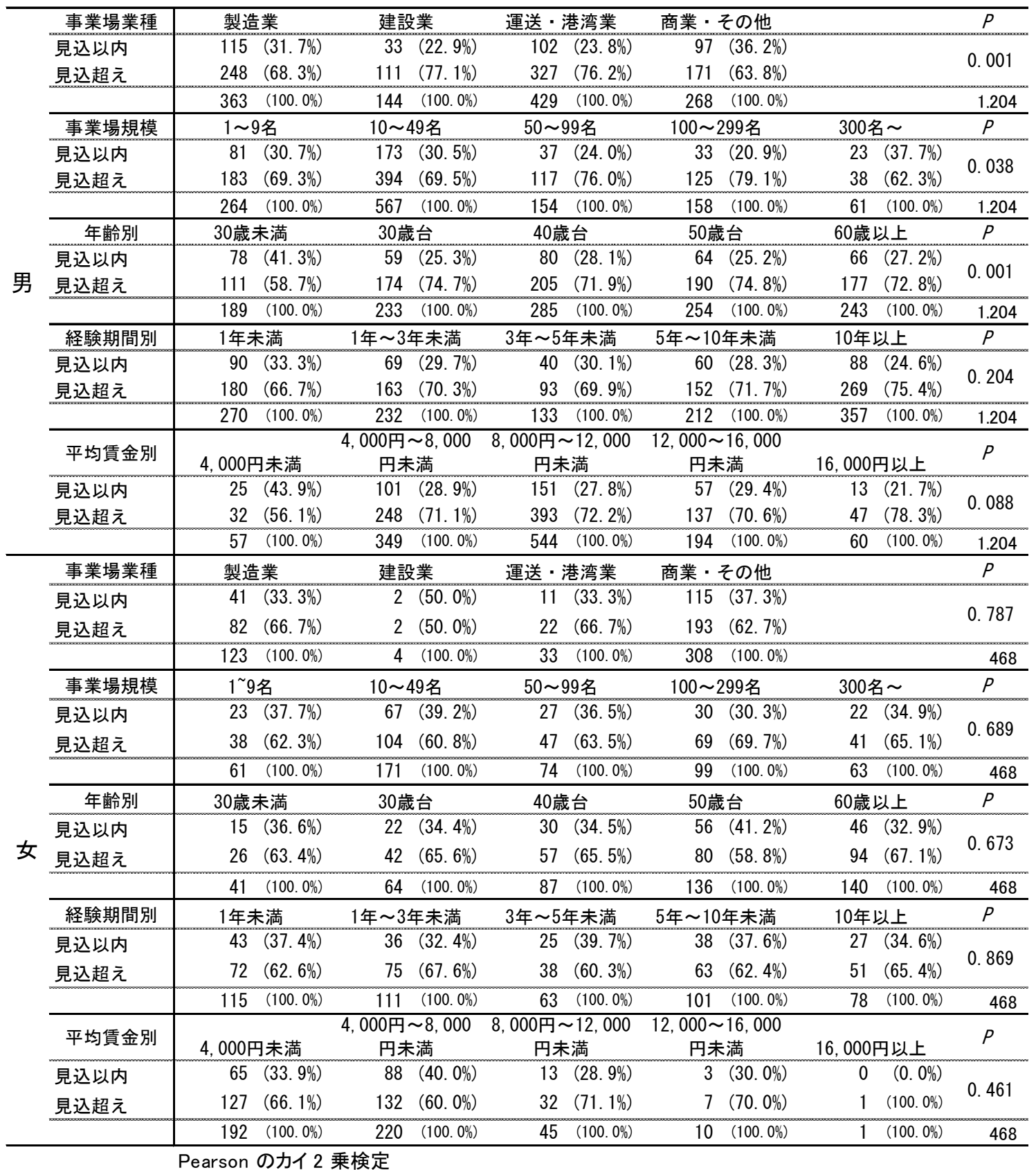

表 4 実休業日数 /休業見込期間と事業場労働者数, 年齢経験期間, 平均賃金の相関（Spearman 相関係数)

\begin{tabular}{|c|c|c|c|c|c|c|}
\hline & & 労働者数 & 年齢 & $\begin{array}{l}\text { 経験期間 } \\
\text { (月表示) }\end{array}$ & 平均賃金 & $\begin{array}{l}\text { 実休業日数 } / \\
\text { 休業見込期間 }\end{array}$ \\
\hline \multirow{5}{*}{ 男 } & 労働者数 & & & & & \\
\hline & 年齢 & -0.020 & & & & \\
\hline & 経験期間（月表示） & -0.055 & $414^{* *}$ & & & \\
\hline & 平均賃金 & -0.015 & -0.003 & $388^{* *}$ & & \\
\hline & 実休業日数／休業見込期間 & 0.048 & $095^{* *}$ & $059 *$ & $.066^{*}$ & \\
\hline \multirow{5}{*}{ 女 } & 労働者数 & & & & & \\
\hline & 年齢 & -0.007 & & & & \\
\hline & 経験期間（月表示） & 0.021 & $.364^{* *}$ & & & \\
\hline & 平均賃金 & 0.013 & $-.161^{* *}$ & $116^{*}$ & & \\
\hline & 実休業日数／休業見込期間 & 0.083 & 0.015 & -0.052 & -0.056 & \\
\hline
\end{tabular}

$* \mathrm{p}<0.05, * * \mathrm{p}<0.01$ 


\section{3 結果}

分析対象とした 3 年間の労働災害 1,672 件（男性 1,204 名, 女性 468名）の被災者の休業見込期間，実休業日数， 所属事業場業種, 事業場労働者数, 年齢, 経験期間, 平 均賃金を表 1 に示した。休業見込期間の中央值は男性 30 日, 女性 28 日と男性で長かった. 実休業日数の中央值 は男性50日, 女性39日であった。業種は男性では運送 ・港湾業が $35.6 \%$ と最も多く, 女性では商業・その他が $65.8 \%$ を占めた. 事業場労働者数の中央值は男性 26 人, 女性 51 人で女性労働者の所属事業場規模が大きかった. 被災者の年齢の中央值は男性 46 歳, 女性 53 歳と女性が 高齢であった．被災までの経験期間の中央值は男性 48 月, 女性36月と男性で長かった。 また, 被災者の平均 賃金額の中央值は男性 9,442円83 銭, 女性 4,632 円 93 銭 と男性で高額であった。

休業見込期間と実休業日数の状況を表 2 に示す。実休 業日数が休業見込期間を超えた者の割合は男性で $71.2 \%$, 女性で $63.9 \%$ であり, 男性の方が有意に高かっ た ( $\mathrm{p}=0.005$, カイ 2乗検定).

表3に実休業日数が休業見込期間を超えた者を男女別 に, 事業場業種, 事業場規模, 年齢別, 経験期間別, 平 均賃金別に示した. 女性ではいずれも関連が認められな かった. しかし, 男性においては, 事業場業種, 事業場 規模, 年齢において有意差が認められた. 残差分析の結 果, 運送・港湾業で休業見込期間を超えて休業していた 者の割合が有意に高かった（76\%, 調整済み標準化残差 の絶対值 $=2.9, \mathrm{p}$ 值=0.004). また, 商業・その他の業 種では休業見込期間を超えて休業していた者の割合が有 意に低かった（64\%, 調整済み標準化残差の絶対值 $=3.0, \mathrm{p}$ 值 $=0.003)$. 事業場規模では, 100～299名の事 業場で休業見込期間を超えて休業していた者の割合が有 意に高かった（79\%, 調整済み標準化残差の絶対值 $=2.4, \mathrm{p}$ 值 $=0.016)$. 被災者の年齢では, 30 歳未満で休 業見込期間を超えて休業していた者の割合が有意に低か つた（59\%, 調整済み標準化残差の絶対值 $=4.1, \mathrm{p}$ 值 $<0.001)$.

実休業日数 / 休業見込期間比を算出し, 労働者数, 年 齢, 経験期間, 平均賃金との相関を表 4 に示す。男性で は実休業日数 /休業見込期間比と年齢, 経験期間, 平均 賃金が有意な相関を示したが，いずれも相関係数は 0.1 未満の弱い相関であった. 女性では実休業日数／休業見 込期間比と有意な相関を示したものはなかった。

表 5 に, 実休業日数 / 休業見込期間比を示す. 平均值 で男性 2.66, 女性 2.54, 中央值は男性 1.38 （範囲 $0.11-$

表 5 男女別 実休業日数 / 休業見込期間

\begin{tabular}{rrrr}
\hline & \multicolumn{1}{c}{ 男 } \\
$(n=1,204)$ & $\begin{array}{c}\text { 女 } \\
(n=468)\end{array}$ & $p$ \\
\hline 平均值 & 2.66 & 2.54 & \\
中央值 & 1.38 & 1.20 & 0.017 \\
最小值 & 0.11 & 0.22 & \\
最大値 & 53.60 & 25.17 & \\
\hline Mann-WhitneyのU検定 & &
\end{tabular}

53.60），女性 $1.20 （$ 範囲 0.22 - 25.17）であった. 男女 ともに実休業日数が休業見达期間を超過しているが, 超 過は, 男性が大きかった（p=0.017, Mann-Whitney のU検定).

\section{4 考察}

労働者死傷病報告により報告されている休業見込期間 で休業を終了している割合は 3 割程度であった。男女と も休業見込期間よりも実休業日数は長くなっていた．労 働基準監督署等においては，労働災害の重篤度を休業見 込期間により判断しているが, 現状では約7割の被災事 例で重篤度を低く見積もってしまうことが示唆される.

大久保らは，労働者の治療費用と賃金の補償が労災保 険で賄われているため, これらの費用を負担しない事業 主は完全に労働能力が回復するまでは職場復帰を歓迎せ ず，早期の復帰には消極的な場合が多い可能性を指摘し ている ${ }^{9)}$. 実休業日数が休業見込期間を超えた労災被災 者が約7割存在したという本研究結果は, この大久保ら の指摘を支持するものといえよう.

本研究では, 男性において, 運送・港湾業で実休業日 数が休業見込期間よりも長くなる者が有意に多いことが 示された．また，商業・その他の業種においては，実休 業日数が休業見込期間よりも長くなる者が有意に少なか った.この違いを生む 1 つの理由として, 仕事内容が考 えられる。運送・港湾業は屋外重筋労働作業が多い. 医 師が日常生活を営むことが可能な程度まで回復している かを基準にして復職見込を判断した場合, 日常生活はで きても肉体的な負担の大きい作業（例えば屋外現場や重 筋労働など）に復帰できないことが理由となって, 復職 までの期間が医師の見込みよりも長くなってしまう。本 結果はこのような事例が少なからずあることを示唆して いるかもしれない. 厚生労働省は, 労安法等に定めの ある「疾病で労働のため病勢が著しく増悪するおそれの あるものにかかった者」の就業禁止規定について,「労 働者の疾病の種類, 程度, これについての産業医等の意 見を勘案してできるだけ配置転換, 作業時間の短縮, そ の他の必要な措置を講ずることによって就業の機会を失 わせないようにし，やむを得ない場合に限り禁止」とす るのが法の趣旨として, 平成 28 年 2 月「事業場におけ る治療と職業生活の両立支援のためのガイドライン」を 発出している ${ }^{10)}$. 被災時の職種・職務へ復帰するのが困 難であるという理由で早期の職場復帰ができないのであ れば，事業場は積極的に職場復帰のための弾力的な働き 方を提供するなどの対応をとる必要がある. 被災者が職 場復帰するために職場環境・労働条件等を整備する必要 があるならば，それは労働災害を発生させた事業場の責 任とすべきであろう。被災時の職種・職務が可能になる まで休業させるということは, 疾病に罹患した者に罹患 前の業務ができるまで就労を認めないという対応と同様 であり, 前出のガイドラインの趣旨にも沿っているとは 言いがたい.

本研究では, 男性において, 事業場規模 100～299人 
の事業場での休業見込期間超えの割合が $79 \%$ で最も， かつ有意に高かった。事業場規模 300 人以上の大企業に おいては, 労務・安全衛生部署において職場復帰へ対応 策等が準備されていることが多い. 心身の状態に応じた 弾力的な働き方を提案することも, 中小規模事業場に比 べて容易であろう。一方で人員の余裕がない中小規模事 業場においては, 休業した者の代替確保が難しいことか ら，事業場から早期の職場復帰が促されたことも考えら れる. 事業場規模 100〜299人の事業場では, 休業した 者の代替確保が優先され, 被災労働者が復職を希望した ときに心身の状態に応じた働き方を提案することは大企 業ほど容易でないかもしれない. そうであれば, 事業場 が配置転換, 作業時間の短縮, その他の必要な措置を講 ずることによって積極的に職場復帰のための弾力的な働 き方を提供できれば，休業見込期間と実休業日数の差異 は縮小するのではないだろうか.

男性において，30歳未満は実休業日数が休業見込期 間よりも長くなる割合が59\%で，他の年齢層に比べて 有意に低かった. 若い者は疾病や障害からの回復が早か った可能性が考えられる. 一方で, 見込まれた休業期間 よりも早く復職できることが真に望ましいことであるか は, 事業場・労働者の双方が慎重に考えなければならな い. 若く経験の短い者は職場復帰への不安から長期休業 をためらい, 必要な療養を終了しないまま職場復帰して しまう可能性も考えられる. 心身の回復が不十分な状態 で就労を再開することが新たな労働災害のリスクになら ないか, 事業場は十分に検討してから復職を決定すべき である.

男女とも労働者数や年齢, 経験期間, 平均賃金と実休 業日数 /休業見込期間比の関連においては, 明確な相関 関係等は認められなかった. ただこれは顕著な単調関係 が存在しなかったことを示しているだけかもしれない. 例えば年齢と実休業日数・休業見込期間の関連について は, 上述の通り, 男性では 30 歳未満では休業見込期間 を超えて復職した者が $59 \%$ で, それ以上の年齢よりも 有意に低かった. 逆に,それ以上のいずれの年齢層でも, 休業見込期間内に復職した者が $70 \%$ 台であった。休業 見込期間を超えて復職した者の割合は, 年齢によって単 調に増加するわけではなかったため, 年齢と実休業日数 ／休業見込期間比の相関は有意であっても低い相関係数 になったと考えられる。

男性は女性に比べて, 実休業日数 / 休業見込期間比が 高かった. 女性は休業見込期間内に復職した者が多かっ た商業・その他に従事する者が多く, 休業見込期間を超 えて復職した者が多かった屋外作業, 重筋作業等に従事 する者が男性に比べて少ないことによるものと考えられ る. 前述の通り, 実休業日数が休業見込期間を超えるこ とを防ぐには，事業場は職場復帰のための弾力的な働き 方を積極的に提供するなどの対応が必要だろう。

最後に本研究の限界について述べる. 本研究は一地域 で行われたものである. 地域により産業構造, 就労者構 成等が異なり, 産業構造等により発生する労働災害の内
容も異なる．本研究を実施した地域は港湾を有する工業 地域であり, 運送・港湾業の労働災害が多発する地域で ある.さらに地域の医療資源等の状況が異なることから, この結果を直ちに一般化できるものではない.

また, 休業請求を伴わない労働災害や死亡災害は含ん でいない，賃金保障を受けることができる有給休暇や特 別休暇の取得により休業・療養する者, 自動車賠償責任 保険・任意保険等により補償された者等については労災 法による労災請求がない場合がある. そのような事例が どの程度あるかを把握することは本研究ではできておら ず，労働災害件数を過小評価している可能性がある.さ らに被災後休業し一旦復職, その後は通院日に休業して いるような場合, 本研究の定義では実休業日数を過大評 価している可能性がある. また休業期間が 1 年以上でも 365 日としたため, この場合は実休業日数を過小評価し ている. また労働者死傷病報告の休業見込期間が専門医 により診断されたものか, 報告者である事業主が把握し て記載したものか等, 労働者死傷病報告の記載内容その もの正確性・妥当性についての検討はしていない. 労働 災害を経緯に退職した者や休業療養中に期間満了・定年 等に達した者等のように, 復帰すべき職場が確保されな かった者の影響は検討できていない，そのため，実休業 日数／休業見込期間比が過小評価されている可能性があ る。

\section{5 結語}

労働災害による休業見込期間と実休業日数の比を検討 したところ, 男女とも実休業日数が休業見込期間を上回 った. 労働災害の重篤度を休業見込期間で判断すること は，重篤度を過小評価する可能性が高い，また，実休業 日数/休業見込期間比は男性が女性より高值であり, 男 性は女性に比較して，休業期間が休業見込期間より長く なっていた。

利益相反

開示すべきCOI状態はない.

\section{文献}

1）中央労働災害防止協会. 安全の指標 平成 30 年度 : 平成 30 年 5 月 30 日.

2) 厚生労働省. 平成 29 年労働災害動向調査（事業所調查（事 業所規模 100 人以上）及び総合工事業調查）の概況. 2018 年 5 月; <https://www.mhlw.go.jp/toukei/itiran/roudou/ saigai/17/dl/2017kekka.pdf>

3）厚生労働省. 労働災害が発生したとき. 2018; https://www. mhlw. go. jp/stf/seisakunitsuite/ bunya/ koyou_roudou/ roudoukijun/zigyonushi/rousai/index.html.

4) 厚生労働省. 第 13 次労働災害防止計画. 2018 年 2 月; < https: / / www. mhlw. go. jp/ file/ 06 - Seisakujouhou11200000 -Roudoukijunkyoku/0000197927.pdf>

5） e-Gov電子政府の総合空口. 労働安全衛生法. 2016; http:// elaws. e- gov. go. jp/ search/ elawsSearch/ elaws_search/

Vol. 12 , No. 3 , pp. 173-179, (2019) 
lsg0500 / detail?lawId=347AC0000000057

6）e-Gov電子政府の総合空口. 労働者災害補償保険法. 2018; http://elaws.e-gov.go.jp/search/elawsSearch/elaws_search/ lsg0 500 / detail? lawId=322 AC0000000050 \& openerCo $\mathrm{de}=1>$

7) 厚生労働省. 労災保険 休業（補償）給付 傷病（補償） 年金の請求手続. 2018年3月; <http://www.mhlw.go.jp/ new-info/kobetu/roudou/gyousei/rousai/dl/040325-13. pdf>

8）e-Gov電子政府の総合空口. 労働基準法. 2018; http:// elaws. e- gov. go. jp/ search/ elawsSearch/ elaws_search/ $\operatorname{lsg} 0500 /$ detail? lawId=322 AC0000000049 \& openerCo $\mathrm{de}=1 \# 80$.

9）大久保利晃. 職場復帰判定の意義・原理. : 産業医科大学産 業生態科学研究所編.,労㗢衛生スタッフのための職場復帰 の理論と実際,平成9年9月25日:p18-p20.

10）厚生労働省. 事業場における治療と職業生活の両立支援の ためのガイドライン. 2016年 2 月; < https://www.mhlw. go.jp/stf/seisakunitsuite/bunya/0000115267.html> 


\title{
Differences between expected and actual length of sick leave attributable to occupational accidents.
}

by

\author{
Yoshiji $\mathrm{KaTOH}^{* 1, * 2}$, Atsuhiko OtA*2, Hiroshi Yatsura*2
}

For prevention of occupational accidents, the Labor Standards Inspection Offices evaluated the severity of the accidents based on the expected length of sick leave which was reported to the offices. Workers who met the accidents often take longer periods of sick leave than expected. We examined the excess of the length and their associations with the workers' characteristics. The subjects were 1,672 workers (1,204 men and 468 women) who met occupational accidents. $71.2 \%$ of the men and $63.9 \%$ of the women took longer periods of sick leave than expected. Men had longer expected (median: 30 days for men, 28 days for women) and actual length of sick leave (median: 50 days for men, 39 days for women) than women. The median rates of the actual sick leave periods to the expected ones were 1.38 for the men and 1.20 for the women. In men, working for the transportation/port industry, a company size of 100-299 employees, and an age of less than 30, were significantly associated with taking longer periods of sick leave than expected. The severity of occupational accidents may be underestimated if it is estimated by the expected sick leave length.

Key Words: Occupational accidents, Expected length of sick leave, Industry type, Age, Sex

*1 Formerly belonging to the Nagoya South Labor Standards Inspection Office

*2 Department of Public Health, Fujita Health University School of Medicine 